\title{
Perceived Quality, Visitor Satisfaction And Conative Loyalty In South African Heritage Museums
}

Laetitia Radder, Nelson Mandela Metropolitan University, South Africa Xiliang Han, Nelson Mandela Metropolitan University, South Africa

\begin{abstract}
Museums are increasingly forced to pay attention to marketing-related aspects such as perceived service quality, satisfaction and loyalty. Using data from three South African heritage museums, this article first delineates the construct of perceived quality and then investigates the relationships between perceived quality, satisfaction and conative loyalty. The resulting perceived quality model comprises two service-based dimensions (service interaction and service evidence) and two product-based dimensions (product functionality and product enrichment). In addition, the results indicate that visitors 'perceived quality has both an indirect effect (through satisfaction) and a direct effect on their behavioral intentions, with the former effect being greater than the latter.
\end{abstract}

Keywords: Conative Loyalty; Heritage Museum; Perceived Quality; South Africa; Visitor Satisfaction

\section{INTRODUCTION}

outh Africa's heritage museums not only have to compete with other cultural attractions for visitors' limited leisure time, but also with numerous other tourism and entertainment options. One way of sustaining heritage museums' patronage is to provide quality experiences and ensure high levels of customer satisfaction because these two achievements contribute to visitor loyalty in terms of word-of-mouth endorsements and repeat visits, and ultimately influence business performance (Baker \& Crompton, 2000).

Our study had two aims - to examine perceived quality associated with the mentioned museums and to determine the relationship between perceived quality, visitor satisfaction and conative loyalty. Neither perceived quality, nor the relationships between quality, satisfaction and loyalty, is a novel area of research. However, we have been intrigued for the following reasons:

- $\quad$ firstly, by the critique that a popular service quality scale, SERVQUAL (Parasuraman, Zeithaml \& Berry, 1988), which focuses on the functional interaction between customers and employees, is inadequate for measuring the quality of hedonic services (Reimer \& Kuehn, 2005) such as museums, and hence requires a more equal balance between tangible and intangible dimensions; and

- $\quad$ secondly, by the conflicting results describing the relationships among quality, satisfaction and loyalty in a tourism context (Žabkar, Brenčič \& Dmitrović, 2010).

\section{LITERATURE REVIEW, CONCEPTUALIZATION AND HYPOTHESES}

\subsection{Perceived Quality}

While quality, an elusive and indistinct construct, lacks a global definition, many definitions seem to have resulted from Garvin's (1984) classical five approaches to quality. These are product-based (quality as measurable attributes), manufacturing-based (quality as conformance to specifications), transcendent (quality as the absolute best), user-based (quality as fitness for use) and value-based (quality as performance at an acceptable price). While the first two approaches allow a fairly objective assessment of quality, objective quality per se, may never exist because all quality is judged by individuals (Zeithaml, 1988). This argument extends the judgement of service quality into that of perceived service quality. 
Perceived service quality is conceptualized following either the 'Nordic' or the 'American' perspective. The 'Nordic' model, consisting of technical, functional, and environmental quality, assumes that consumers will judge service quality based on the outcome, the process creating the outcome, and the physical surroundings of the service (Grönroos, 1984; Rust \& Oliver, 1994). The 'American' approach, which holds that customers judge service quality on five distinct dimensions (tangibles, reliability, responsiveness, assurance and empathy), has received considerably more attention from academics and practitioners, mainly owing to the introduction of SERVQUAL (Parasuraman et al, 1988).

Despite its wide application in different environments, SERVQUAL has been criticized for its asymmetry between tangible and functional dimensions. Except for one dimension describing the tangible elements of the service, all the other dimensions measure the functional interaction between customers and employees. This underestimation of the tangibles could be explained by the fact that SERVQUAL was based on services (e.g. financial services) where customers tend to have only a superficial knowledge of tangibles (Sánchez-Hernández, Martínez-Tur, Peiró \& Ramos, 2009).

Reimer and Kuehn (2005) have found that museum visitors spend considerable time in the service environment and place a great deal of emphasis on the service process. Raajpoot, Koh and Jackson (2010), on the other hand, argue that visitors take numerous physical aspects, such as exhibitions and the building itself, into account when assessing their visits, but tend to judge them from a holistic perspective such as ambiance. We have purposefully included items in our study that span the continuum from physical products to intangible services to get a more holistic representation.

\subsection{Customer Satisfaction}

At least nine distinct theories of customer satisfaction exist in the literature: expectancy-disconfirmation, assimilation, contrast, assimilation-contrast, equity, attribution, comparison-level, generalized negativity and value-perception (Oh \& Parks, 1997). The Expectancy-Disconfirmation Paradigm (EDP) seems to have received most attention in the satisfaction literature. EDP suggests a comparison between expectations and actual experiences, which results in confirmation, positive disconfirmation, or negative disconfirmation (Oliver, 1980). Confirmation and positive disconfirmation lead to satisfaction, while negative disconfirmation leads to dissatisfaction.

Despite the dominance of EDP, a debate about the inclusion of expectations in the satisfaction scale still remains. EDP is based on the assumption that everyone has firm expectations prior to experiences. Confirmation or disconfirmation of expectations thus cannot occur without such advance expectations (Yüksel \& Yüksel, 2001). However, this assumption may be incorrect in the tourism context because tourism offerings are based more on experience and credence properties than on search properties (Brucks, Zeithaml \& Naylor, 2000). This means that tourists (particularly first-timers) do not establish expectations until they have experienced the service. Museums are typically infrequently visited, making it difficult to formulate pre-visit expectations; therefore, we focused on actual experience only.

\subsection{Customer Loyalty}

Oliver (1999) differentiates among four sequential stages in the development of loyalty. Customers typically first show information-driven cognitive loyalty, which later on develops into affective loyalty associated with positive feelings toward the offering or provider. Conative loyalty - the third stage - reflects customers' behavioral intentions, which culminates in action loyalty. The first three stages are part of attitudinal loyalty, while the last phase is linked to behavioral loyalty.

Zeithaml, Berry and Parasuraman (1996) identified five favorable behavioral intentions, namely, to say positive things about the service provider, to recommend the provider to other customers, to remain loyal to the provider, to spend more with the provider, and to pay price premiums. Within the tourism context, visitor loyalty is frequently associated with intentions to revisit and word-of-mouth communications (e.g. Hui, Wan \& Ho, 2007). In following previous research into the loyalty of museum visitors (e.g. Harrison \& Shaw, 2004; Huo \& Miller, 2007; Simpson, 2000; Yucelt, 2000), we opted to investigate conative loyalty as part of the interrelationship between quality, satisfaction and loyalty with a focus on word-of-mouth communication and revisit intentions. 


\subsection{The Quality, Satisfaction and Loyalty Relationships}

An analysis of 43 studies published in three tourism journals regularly used for critical meta-review purposes (Bigné, Gnoth \& Andreu, 2008; Hsu, Cai \& Li, 2010), namely, Annals of Tourism Research, Journal of Travel Research and Tourism Management, showed that of the 13 studies that examined the Quality $\rightarrow$ Satisfaction link, 10 confirmed quality as an antecedent to satisfaction, and the rest found an insignificant relationship between these constructs. Fourteen studies assessed the Quality $\rightarrow$ Loyalty link, of which eight recognized a direct relationship, four identified an indirect relationship through satisfaction $(\mathrm{Q} \rightarrow \mathrm{S} \rightarrow \mathrm{L})$, and two denied either a direct or an indirect relationship. The overwhelming majority of the selected studies successfully validated the Satisfaction $\rightarrow$ Loyalty link. The key findings of these studies are summarized in the Appendix.

Building on the existing knowledge of quality, satisfaction and loyalty, and the relationships between these concepts, we proposed the following hypotheses for our research:

Hypothesis 1 (H1): Perceived quality affects visitor satisfaction positively and directly (PQ $\rightarrow \mathrm{VS})$.

Hypothesis 2 (H2): Perceived quality affects conative loyalty positively and directly $(\mathrm{PQ} \rightarrow \mathrm{CL})$.

Hypothesis 3 (H3): Visitor satisfaction affects conative loyalty positively and directly (VS $\rightarrow$ CL).

Hypothesis 4 (H4): Visitor satisfaction has a mediating effect on the relationship between perceived quality and conative loyalty $(\mathrm{PQ} \rightarrow \mathrm{VS} \rightarrow \mathrm{CL})$.

\section{RESEARCH METHODOLOGY}

\subsection{Questionnaire Design}

One section of our self-administered questionnaire contained 15 service-related and 10 product-related attributes (items) intended to measure perceived quality on a five-point Likert-type scale ranging from 1, denoting a very negative evaluation, to 5, describing a very positive rating. Service attributes originated from Akama and Kieti (2002) and McLean (1997), while product attributes were sourced from Rowley (1999) and Phaswana-Mafuya and Haydam (2005). The selected items were checked for content validity by two experts.

Another section measured visitor satisfaction and conative loyalty. Two items, adapted from Oliver (1997), were used to measure respondents' satisfaction with the overall visiting experience. These items were: "I was pleased with my visit to this museum" (abbreviated as PLZ) and "visiting this museum was a wise choice" (CHO). Conative loyalty was measured by two items adapted from Zeithaml et al (1996), which were: "I will revisit this museum in the next few years" (REV) and "I will recommend this museum to my friends and relatives" (WOM). Respondents were asked to rate their satisfaction and loyalty on a five-point Likert-type scale with 1 being 'strongly disagree' and 5 being 'strongly agree'.

The last section of the questionnaire recorded respondents' socio-demographic and travel-related characteristics, using a categorical scale. Characteristic variables included gender, age, education, income, place of residence, travel party, and information sources. All the statements constituting the questionnaire have been tested in a pilot study with 15 museum visitors.

\subsection{Data Collection and Analysis}

Three heritage museums situated in the Nelson Mandela Bay area, South Africa, served as the collection points for our primary data. They were No.7 Castle Hill Museum, South End Museum, and Red Location Museum. The lack of a complete sampling frame of visitor populations prevented us from undertaking probability sampling. We therefore chose a quota-and-convenience mixed sampling method. Considering the type of the analysis and the number of items, the targeted sample size equaled $3 \%$ of the total number of visitors to each of the museums in the preceding year. As a result, 267 questionnaires were conveniently distributed in face-to-face interviews at the museums, according to the said quotas. Two hundred and twelve questionnaires (a response rate of 79.4\%) were valid and could be coded for data analysis.

SPSS 15 and AMOS 7 software packages were used to perform Exploratory Factor Analysis (EFA), Confirmatory Factor Analysis (CFA) and Structural Equation Modelling (SEM). The following section presents and discusses the analytical results. 


\section{EMPIRICAL FINDINGS}

\subsection{Profile of Respondents}

Socio-demographic data indicated that $57 \%$ of the respondents were female; $58 \%$ were younger than 35 years, and $37 \%$ were $35-64 ; 65 \%$ had received higher education; $39 \%$ had a monthly gross income of R10, 000 or more (10 Rand $\approx 1$ US dollar during the survey); and 53\% lived in the Nelson Mandela Bay area, 24\% elsewhere in South Africa and $23 \%$ in other countries.

Results of the travel-related data analysis showed that $59 \%$ of the respondents were visiting the museums with family and friends and $28 \%$ as part of tour groups. Word-of-mouth publicity (77\%) emerged as the key information source for respondents to learn about the museums.

\section{2. $\quad$ Factor Solutions of Perceived Quality}

EFAs separately sought the underlying dimensions of service- and product-related quality attributes, using principal components analysis extraction and oblique rotation. As for the data of service-related attributes, the Kaiser-Meyer-Olkin (KMO) measure of sampling adequacy was 0.78 , slightly below the 'meritorious' level of 0.80 (Kaiser, 1974). The Bartlett's test of sphericity was significant $(\mathrm{p}<0.001)$, detecting the correlations among the indicators (Bartlett, 1954). The use of factor analysis for the data of interest was thus justified.

Eigenvalues, screeplot patterns and percentages of variance were all taken into account to determine the appropriate number of factors. Two eigenvalues exceeded 1.0 (3.38 and 2.08, respectively) and a clear elbow appeared after the second component in the screeplot, both suggesting the existence of two latent factors (Cattell, 1966; Kaiser, 1960). The two factors together explained $68.3 \%$ of the total variance $(42.3 \%$ and $26.0 \%$, respectively), meeting the rule of thumb in the social sciences that a satisfactory factor solution should account for at least $60 \%$ of the total variance, and a meaningful factor should account for at least 5\% of the total variance (Hair, Black, Babin \& Anderson, 2010). Given these, we deemed a two-factor solution acceptable.

As suggested by Hair et al (2010), items exhibiting low factor loadings $(<0.50)$, high cross-loadings $(>0.50)$ or low communalities $(<0.50)$ were removed one at a time. This process continued until no more items were to be deleted. Eight items were retained as the composition of the two-factor solution (Table 1). Thereafter, Cronbach's alphas (Nunnally, 1978) were calculated. Both factors showed adequate internal consistency (0.84 and 0.83, respectively), and the two factors were labeled as Service Interaction (SI) and Service Evidence (SE).

Table 1: Results of EFA for Service-Related Attributes

\begin{tabular}{|l|c|c|c|c|c|}
\hline \multicolumn{1}{|c|}{ Variable } & $\begin{array}{c}\text { Factor } \\
\text { Loading }\end{array}$ & Communality & $\begin{array}{c}\text { Eigen- } \\
\text { Value }\end{array}$ & $\begin{array}{c}\text { Variance } \\
(\%)\end{array}$ & $\begin{array}{c}\text { Cronbach's } \\
\text { Alpha }\end{array}$ \\
\hline Service Interaction (SI) & & & 3.38 & 42.25 & 0.84 \\
\hline SI1: Staff are willing to assist me & 0.90 & 0.81 & & & \\
\hline SI2: Staff meet their promises on time & 0.85 & 0.69 & & & \\
\hline SI3: Staff give me personal attention & 0.81 & 0.65 & & & \\
\hline SI4: Staff have knowledge to answer my questions & 0.75 & 0.61 & & & \\
\hline Service Evidence (SE) & & & 2.08 & 26.02 & 0.83 \\
\hline SE1: Comfortable level of lighting & 0.86 & 0.73 & & & \\
\hline SE2: Comfortable temperature & 0.85 & 0.74 & & & \\
\hline SE3: Clear sign posting and directions & 0.79 & 0.61 & & & \\
\hline SE4: Clean air & 0.76 & 0.63 & & & \\
\hline
\end{tabular}

The above EFA procedure was duplicated to purify the data of product-related attributes. The appropriateness of factor analysis was evident because the KMO score was 0.76 and the Bartlett's test of sphericity had statistical significance $(\mathrm{p}<0.001)$. The resulting two-factor solution with seven items (Table 2) had eigenvalues of 3.26 and 1.46, variances of $46.6 \%$ and $20.9 \%$, and Cronbach's alphas of 0.80 and 0.88 , respectively. The two factors were labeled as Product Functionality (PF) and Product Enrichment (PE). 
Table 2: Results of EFA for Product-Related Attributes

\begin{tabular}{|l|c|c|c|c|c|}
\hline \multicolumn{1}{|c|}{ Variable } & $\begin{array}{c}\text { Factor } \\
\text { Loading }\end{array}$ & Communality & Eigen-Value & $\begin{array}{c}\text { Variance } \\
(\%)\end{array}$ & $\begin{array}{c}\text { Cronbach's } \\
\text { Alpha }\end{array}$ \\
\hline Product Functionality $(P F)$ & & & 3.26 & 46.61 & 0.80 \\
\hline PF1: Easy to find museum's physical location & 0.86 & 0.68 & & & \\
\hline PF2: Easy to understand exhibitions & 0.75 & 0.55 & & & \\
\hline PF3: Easy to access museum setting & 0.73 & 0.61 & & & \\
\hline PF4: Easy to use facilities & 0.67 & 0.51 & & 20.89 & 0.88 \\
\hline Product Enrichment $(P E)$ & & & 1.46 & & \\
\hline PE1: Free maps or brochures provided & 0.95 & 0.86 & & & \\
\hline PE2: Useful promotional material & 0.87 & 0.77 & & & \\
\hline PE3: Comfortable resting area & 0.86 & 0.78 & & & \\
\hline
\end{tabular}

\subsection{Holistic Measurement Model of Perceived Quality}

CFA was followed, using the maximum likelihood estimation method to combine the two solutions into a holistic measurement model of perceived quality. Given the sensitivity of the chi-square statistic to sample size and model complexity, this study employed normed chi-square to evaluate model fit, yielding a cut-off ratio of 5:1 (Klem, 2000). In addition, two absolute fit indices (RMR and GFI) and two incremental fit indices (CFI and TLI) were selected for model assessment, subject to cut-off values of 0.05, 0.90, 0.90 and 0.90 respectively (Thompson, 2000).

The holistic measurement model viewing perceived quality as a function of SI, SE, PF and PE, was subjected to the goodness-of-fit test. The results of $\chi^{2} / \mathrm{df}=2.63, \mathrm{RMR}=0.05, \mathrm{GFI}=0.90, \mathrm{CFI}=0.92$ and TLI $=0.91$ proved that the holistic model had a good fit to the data. In addition, the holistic model showed adequate convergent and discriminant validity (Figure 1), as evidenced by fairly high standardized loadings $(>0.50)$ and acceptable values for Construct Reliability (CR > 0.70), Average Variance Extracted (AVE > 0.50) and Fornell-Larcker-Ratio (FLR < 1.0) (Fornell \& Larcker, 1981; Hair et al, 2010).

Having established the holistic measurement model of perceived quality, four summated scales were created to denote the SI, SE, PF and PE constructs. These summated scales were then used as manifest variables for the latent variable 'perceived quality' in the subsequent SEM analysis. 


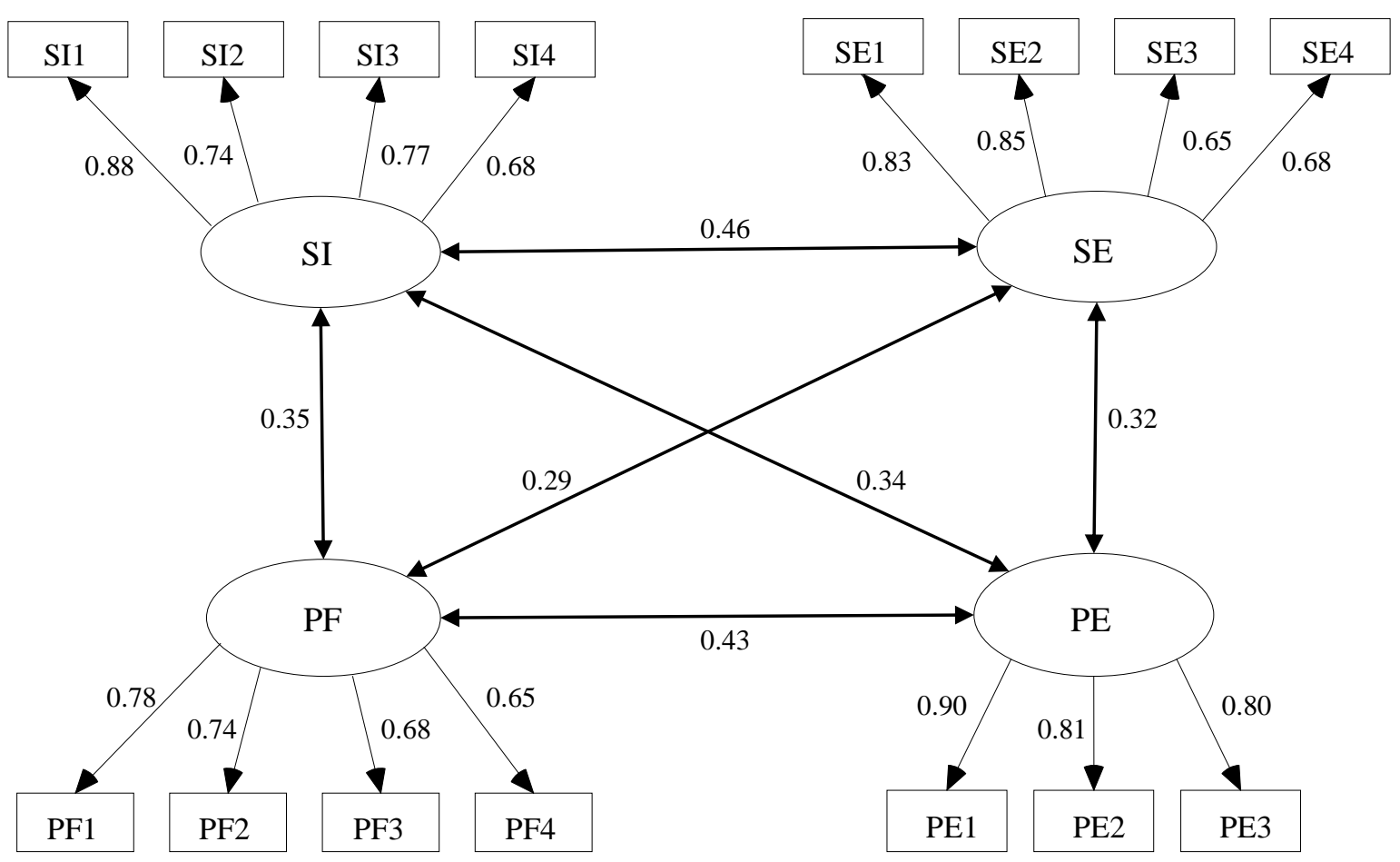

Figure 1: Holistic Measurement Model of Perceived Quality Notes: SI: $\mathrm{CR}=0.85, \mathrm{AVE}=0.59, \mathrm{FLR}=0.36$; $\mathrm{SE}: \mathrm{CR}=0.84, \mathrm{AVE}=0.57$, FLR $=0.37$

PF: $\mathrm{CR}=0.81, \mathrm{AVE}=0.51, \mathrm{FLR}=0.36$; $\mathrm{PE}: \mathrm{CR}=0.88, \mathrm{AVE}=0.70, \mathrm{FLR}=0.26$

\subsection{Structural Equation Modelling and Hypothesis Testing}

The SEM model contained a three-construct measurement model. Perceived quality was viewed as an exogenous construct, measured by four reflective indicators; visitor satisfaction and conative loyalty acted as endogenous constructs, each measured by two reflective indicators. The three-construct measurement model had a good fit to the data $\left(\chi^{2} / \mathrm{df}=1.88, \mathrm{RMR}=0.03, \mathrm{GFI}=0.95, \mathrm{CFI}=0.96\right.$ and TLI $\left.=0.93\right)$ and respectable evidence of convergent and discriminant validity as shown in Figure 2. 


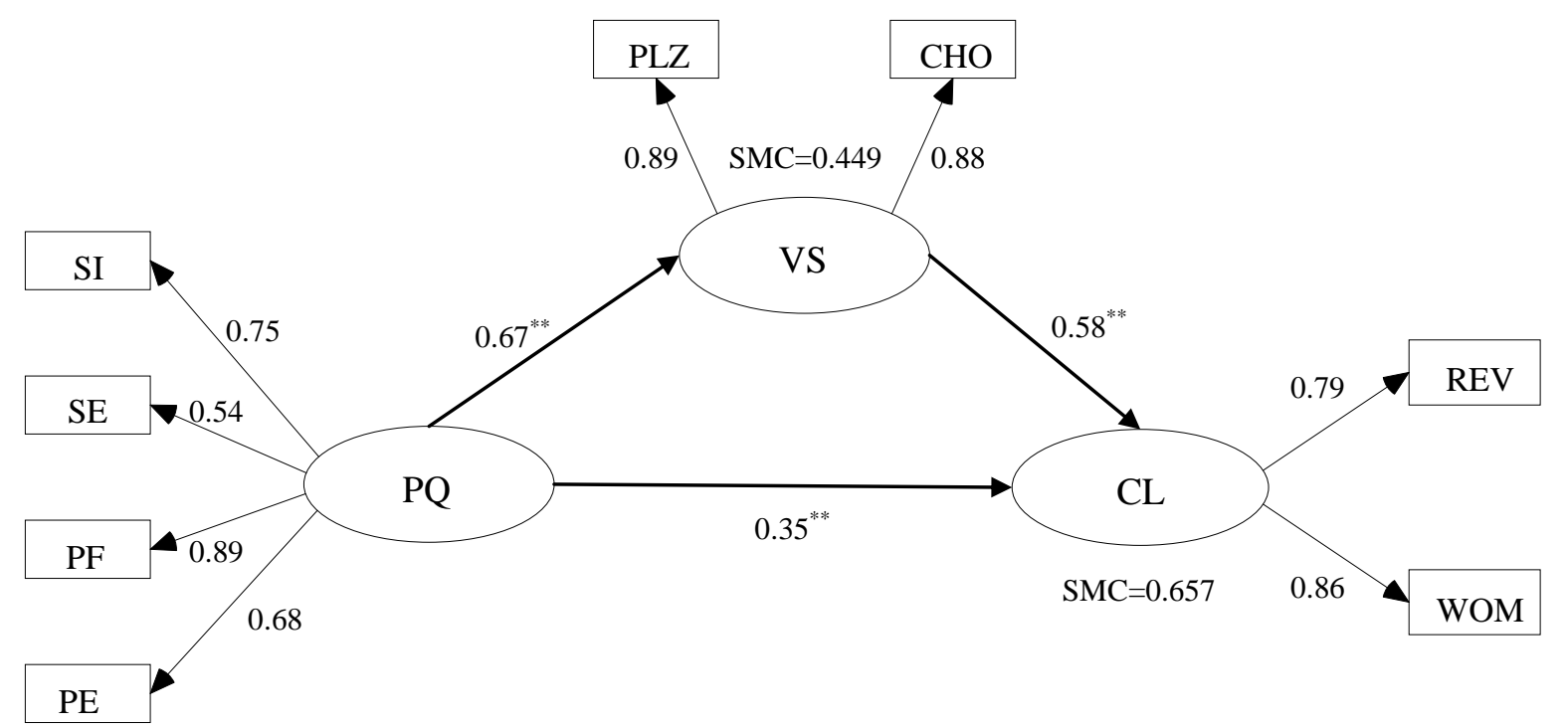

Figure 2: The SEM Model

Notes: PQ: $\mathrm{CR}=0.81, \mathrm{AVE}=0.53$, FLR=0.85; VS: $\mathrm{CR}=0.88, \mathrm{AVE}=0.78, \mathrm{FLR}=0.58$

$\mathrm{CL}: \mathrm{CR}=0.81, \mathrm{AVE}=0.68, \mathrm{FLR}=0.57 ; * * \mathrm{p}<0.01$

The SEM model also contained a structural model which was assessed with the aim of testing the proposed hypotheses. This assessment process involved estimating both path coefficients and Squared Multiple Correlations (SMCs). The structural model included two gamma paths $(\mathrm{PQ} \rightarrow \mathrm{VS}$ and $\mathrm{PQ} \rightarrow \mathrm{CL})$ and one beta path $(\mathrm{VS} \rightarrow \mathrm{CL})$, the coefficients of which disclosed the extent of the relationships between the independent and dependent variables. SMC is similar to the $\mathrm{R}^{2}$ value in regression analysis and indicates the amount of variance in an endogenous variable explained by one or more exogenous variables (Hair et al, 2010). In our study, $44.9 \%$ of the variance in visitor satisfaction was explained by perceived quality and $65.7 \%$ of the variance in conative loyalty was explained by perceived quality and visitor satisfaction.

Figure 2 presents the outcome of SEM: (1) perceived quality positively influenced conative loyalty $(\gamma=0.35)$; (2) perceived quality positively affected visitor satisfaction $(\gamma=0.67)$; and (3) visitor satisfaction positively influenced conative loyalty $(\beta=0.58)$. Therefore, the first three hypotheses $(\mathrm{H} 1, \mathrm{H} 2$ and $\mathrm{H} 3)$, which proposed direct causality among perceived quality, visitor satisfaction, and conative loyalty, could not be rejected. Besides, visitor satisfaction showed a mediating effect according to the SEM result. Consequently, the last hypothesis (H4) was also not rejected.

\section{THEORETICAL AND MANAGERIAL IMPLICATIONS}

This article dealt with the measurement of visitors' perceptions of quality and the associations between perceived quality, satisfaction and loyalty within the heritage museum context.

Our aim was not to test and validate the application of the SERVQUAL scale in our study, but rather to examine perceived quality of the heritage museums using a balance between tangible and intangible attributes and with a lesser focus on the functional interaction between customer and employee prominent in SERVQUAL. Our results led to the delineation of two service-related quality dimensions (service interaction and service evidence) and two product-related quality dimensions (product functionality and product enrichment). These quality dimenions can now be tested in other museum settings and the context of other cultural attractions such as ethnic villages. It was found that service interaction and product functionality have a stronger influence on their corresponding quality facets (Figure 2). These two key drivers of perceived quality should therefore be the focus of museum management activities.

The second aim of our study was to investigate the relatioships among quality, satisfaction and loyalty in our museums. Our research supports the hypothesis that quality has both an indirect effect (through satisfaction) and a direct effect on visitors' behavioral intentions. This finding corroborates the results of other studies in tourism (e.g. 
Campo \& Yagüe, 2008). In addition, we also found that quality (total effect $=0.74$ ) is a better predictor of behavioral intentions than satisfaction (total effect $=0.58$ ). This is consistent with the conclusion made by researchers such as Petrick (2004b). These findings could be beneficial to the prediction of behavioral intentions beyond those of museum visitors because Žabkar et al (2010) comment that "attributes...cannot be generalised across destinations. What can be generalised are the relationships between the three constructs" (p.543).

Museum managers should note that although both direct and indirect effects of perceived quality on conative loyalty were identified, the latter (0.39) is greater than the former (0.35). This implies that visitor satisfaction plays a significant role, not only in predicting behavioral intentions independently, but also in enhancing the predictive power of quality on loyalty. Therefore, museum managers will be better able to understand the purchase decision-making process of museum visitors if they simultaneously utilize quality and satisfaction as independent variables in the prediction of behavioral intentions.

\section{LIMITATIONS AND SUGGESTIONS FOR FUTURE RESEARCH}

The limitations of our study opened pathways for future research. First of all, since the population of this survey was limited to visitors of specific heritage museums in South Africa, the generalizability of the findings may be questioned. Both cross-sectional and longitudinal future research can help determine whether different visitor and museum samples will yield similar results.

Secondly, our study examined only perceived quality and satisfaction as antecedents to conative loyalty. Since additional variables, such as customer value (e.g. Chen \& Chen, 2010), emotions (Yüksel \& Yüksel, 2007) and motivation (e.g. Yoon \& Uysal, 2005), may also predict customer behavior, further research is necessary to investigate the antecedent role of these additional variables in a heritage museum context.

Finally, additional research is needed to examine the model's effectiveness and stability across tourism settings other than heritage museums.

\section{ACKNOWLEDGEMENTS}

This work is based on the research supported by the National Research Foundation of South Africa (Grant specific unique reference number (UID) 85602). The Grantholder acknowledges that opinions, findings and conclusions or recommendations expressed in any publication generated by the NRF supported research are that of the author(s) and that the NRF accepts no liability whatsoever in this regard.

\section{AUTHOR INFORMATION}

Laetitia Radder, D Com, is a Professor of Marketing at the Nelson Mandela Metropolitan University, Port Elizabeth, South Africa. Her research focuses on marketing, consumer behavior and the experience economy. E-mail: Laetitia.Radder@nmmu.ac.za (Corresponding author)

Xiliang Han is a PhD student at the Department of Marketing Management, Nelson Mandela Metropolitan University, Port Elizabeth, South Africa. His research interests include consumer behavior, service and experience marketing within the travel and tourism sector. E-mail: Xiliang.Han@nmmu.ac.za

\section{REFERENCES}

1. Akama, J. S. \& Kieti, D. M. (2002). Measuring tourist satisfaction with Kenya's wildlife safari: A case study of Tsavo West National Park. Tourism Management, 23, 73-81.

2. Alegre, J. \& Cladera, M. (2006). Repeat visitation in mature sun and sand holiday destinations. Journal of Travel Research, 44 (February), 288-297.

3. Alegre, J. \& Garau, J. (2010). Tourist satisfaction and dissatisfaction. Annals of Tourism Research, 37(1), 52-73.

4. Baker, D. \& Crompton, J. (2000). Quality, satisfaction and behavioral intentions. Annals of Tourism Research, 27(3), 785-804. 
5. Bartlett, M. (1954). A note on the multiplying factors for various chi square approximations. Journal of the Royal Statistical Society, 16(2), 296-298.

6. Bigné, E., Andreu, L. \& Gnoth, J. (2005). The theme park experience: An analysis of pleasure, arousal and satisfaction. Tourism Management, 26, 833-844.

7. Bigné, E., Gnoth, J. \& Andreu, L. (2008). Advanced topics in tourism market segmentation. In A. Woodside \& D. Martin, eds. Tourism management: Analysis, behaviour and strategy, 151-173. Oxford: CABI.

8. Brucks, M., Zeithaml, V. \& Naylor, G. (2000). Price and brand name as indicators of quality dimensions for consumer durables. Journal of the Academy of Marketing Science, 28(3), 359-374.

9. Campo, S. \& Yagüe, M. (2008). Tourist loyalty to tour operator: Effects of price promotions and tourist effort. Journal of Travel Research, 46 (February), 318-326.

10. Campo-Martínez, S., Garau-Vadell, J. \& Martínez-Ruiz, M. (2010). Factors influencing repeat visits to a destination: The influence of group composition. Tourism Management, 31, 862-870.

11. Castro, C., Martín Armario, E. \& Martín Ruiz, D. (2007). The influence of market heterogeneity on the relationship between a destination's image and tourists' future behaviour. Tourism Management, 28, 175-187.

12. Cattell, R. (1966). The scree test for the number of factors. Multivariate Behavioral Research, 1, 245-276.

13. Chen, C. \& Chen, F. (2010). Experience quality, perceived value, satisfaction and behavioral intentions for heritage tourists. Tourism Management, 31, 29-35.

14. Chen, C. \& Tsai, D. (2007). How destination image and evaluative factors affect behavioral intentions? Tourism Management, 28, 1115-1122.

15. Chen, C. \& Tsai, M. (2008). Perceived value, satisfaction, and loyalty of TV travel product shopping: Involvement as a moderator. Tourism Management, 29, 1166-1171.

16. Chi, C. \& Qu, H. (2008). Examining the structural relationships of destination image, tourist satisfaction and destination loyalty: An integrated approach. Tourism Management, 29(4), 624-636.

17. De Rojas, C. \& Camarero, C. (2008). Visitors' experience, mood and satisfaction in a heritage context: Evidence from an interpretation center. Tourism Management, 29, 525-537.

18. Duman, T. \& Mattila, A. (2005). The role of affective factors on perceived cruise vacation value. Tourism Management, 26, 311-323.

19. Fornell, C. \& Larcker, D. (1981). Evaluating structural equation models with unobservable variables and measurement error. Journal of Marketing Research, 18 (February), 39-50.

20. Füller, J. \& Matzler, K. (2008). Customer delight and market segmentation: An application of the three-factor theory of customer satisfaction on life style groups. Tourism Management, 29, 116-126.

21. Gallarza, M. \& Saura, I. (2006). Value dimensions, perceived value, satisfaction and loyalty: An investigation of university students' travel behaviour. Tourism Management, 27, 437-452.

22. Garvin, D. (1984). What does 'product quality' really mean? Sloan Management Review, 26(1), 25-43.

23. Grönroos, C. (1984). A service quality model and its marketing implications. European Journal of Marketing, 18(4), 36-44.

24. Hair, J., Black, W., Babin, B. \& Anderson, R. (2010). Multivariate data analysis: A global perspective. Upper Saddle River: Pearson Education.

25. Harrison, P. \& Shaw, R. (2004). Consumer satisfaction and post-purchase intentions: An exploratory study of museum visitors. International Journal of Arts Management, 6(2), 23-32.

26. He, Y. \& Song, H. (2009). A mediation model of tourists' repurchase intentions for packaged tour services. Journal of Travel Research, 47(3), 317-331.

27. Ho, C. \& Lee, Y. (2007). The development of an e-travel service quality scale. Tourism Management, 28, 1434-1449.

28. Hosany, S. \& Gilbert, D. (2010). Measuring tourists' emotional experiences toward hedonic holiday destinations. Journal of Travel Research, 49(4), 513-526.

29. Hosany, S. \& Witham, M. (2010). Dimensions of cruisers' experiences, satisfaction, and intention to recommend. Journal of Travel Research, 49(3), 351-364.

30. Hsu, C., Cai, L. \& Li, M. (2010). Expectation, motivation, and attitude: A tourist behavioral model. Journal of Travel Research, 49(3), 282-296.

31. Huang, S. \& Hsu, C. (2009). Effects of travel motivation, past experience, perceived constraint, and attitude on revisit intention. Journal of Travel Research, 48(1), 29-44.

32. Hui, T., Wan, D. \& Ho, A. (2007). Tourists' satisfaction, recommendation and revisiting Singapore. Tourism Management, 28(4), 965-975.

33. Huo, Y. \& Miller, D. (2007). Satisfaction measurement of small tourism sector (museum): Samoa. Asia Pacific Journal of Tourism Research, 12(2), 103-117. 
34. Hutchinson, J., Lai, F. \& Wang, Y. (2009). Understanding the relationships of quality, value, equity, satisfaction, and behavioral intentions among golf travelers. Tourism Management, 30, 298-308.

35. Jang, S. \& Feng, R. (2007). Temporal destination revisit intention: The effects of novelty seeking and satisfaction. Tourism Management, 28, 580-590.

36. Kaiser, H. (1960). The application of electronic computers to factor analysis. Educational and Psychological Measurement, 20, 141-151.

37. Kaiser, H. (1974). Little Jiffy, Mark IV. Educational and Psychological Measurement, 34, 111-117.

38. Kim, T., Kim, W. \& Kim, H. (2009). The effects of perceived justice on recovery satisfaction, trust, word-of-mouth, and revisit intention in upscale hotels. Tourism Management, 30, 51-62.

39. Klem, L. (2000). Structural equation modeling. In L. Grimm \& P. Yarnold, eds. Reading and understanding more multivariate statistics, 227-260. Washington, DC: American Psychological Association.

40. Kozak, M. (2001). Repeaters' behavior at two distinct destinations. Annals of Tourism Research, 28(3), 784-807.

41. Lee, S., Petrick, J. \& Crompton, J. (2007). The role of quality and intermediary constructs in determining festival attendees' behavioral intention. Journal of Travel Research, 45(4), 402-412.

42. Lee, C., Yoon, Y. \& Lee, S. (2007). Investigating the relationships among perceived value, satisfaction, and recommendations: The case of the Korean DMZ." Tourism Management, 28, 204-214.

43. Li, X. \& Petrick, J. (2008). Examining the antecedents of brand loyalty from an investment model perspective. Journal of Travel Research, 47 (August), 25-34.

44. McLean, F. (1997). Marketing the museum. New York: Routledge.

45. Nunnally, J. (1978). Psychometric theory. New York: McGraw-Hill.

46. Oh, H. \& Parks, S. (1997). Customer satisfaction and service quality: A critical review of the literature and research implications for the hospitality industry." Hospitality Research Journal, 20(3), 36-64.

47. Oliver, R. (1980). A cognitive model of the antecedents and consequences of satisfaction decisions. Journal of Marketing Research, 17 (November), 460-469.

48. Oliver, R. (1997). Satisfaction: A behavioral perspective on the consumer. New York: Irwin.

49. Oliver, R. (1999). Whence consumer loyalty? Journal of Marketing, 63 (Special issue), 33-44.

50. Parasuraman, A., Zeithaml, V. \& Berry, L. (1988). SERVQUAL: A multiple-item scale for measuring consumer perceptions of service quality. Journal of Retailing, 64(1), 12-40.

51. Phaswana-Mafuya, N. \& Haydam, N. 2005. Tourists' expectations and perceptions of the Robben Island Museum - a world heritage site. Museum Management and Curatorship, 20(2), 149-169.

52. Petrick, J. (2004a). First timers' and repeaters' perceived value. Journal of Travel Research, 43 (August), 29-38.

53. Petrick, J. (2004b). The roles of quality, value, and satisfaction in predicting cruise passengers' behavioral intentions. Journal of Travel Research, 42 (May), 397-407.

54. Petrick, J. \& Backman, S. (2002). An examination of the determinants of golf travelers' satisfaction. Journal of Travel Research, 40 (February), 252-258.

55. Petrick, J., Morais, D. \& Norman, W. (2001). An examination of the determinants of entertainment vacationers' intentions to revisit. Journal of Travel Research, 40 (August), 41-48.

56. Raajpoot, N., Koh, K. \& Jackson, A. (2010). Developing a scale to measure service quality: An exploratory study. International Journal of Arts Management, 12(3), 54-69.

57. Reimer, A. \& Kuehn, R. (2005). The impact of servicescape on quality perception. European Journal of Marketing, 39(7/8), 785-808.

58. Rentschler, R. \& Gilmore, A. (2002). Museums: Discovering services marketing. International Journal of Arts Management, 5(1), 62-72.

59. Rodríguez del Bosque, I. \& San Martín, H. (2008). Tourist satisfaction: A cognitive-affective model. Annals of Tourism Research, 35(2), 551-573.

60. Rodríguez del Bosque, I., San Martín, H. \& Collado, J. (2006). The role of expectations in the consumer satisfaction formation process: Empirical evidence in the travel agency sector. Tourism Management, 27, 410-419.

61. Rowley, J. 1999. Measuring total customer experience in museums. International Journal of Contemporary Hospitality Management, 11(6), 303-308.

62. Rust, R. \& Oliver, R. (1994). Service quality: Insights and managerial implications from the frontier. In R. Rust \& R. Oliver, eds. Service quality: New directions in theory and practice, 1-19. Thousand Oaks: Sage. 
63. Sánchez-Hernández, R., Martínez-Tur, V., Peiró, J. \& Ramos, J. (2009). Testing a hierarchical and integrated model of quality in the service sector: Functional, relational, and tangible dimensions. Total Quality Management, 20(11), 1173-1188.

64. Severt, D., Wang, Y., Chen, P. \& Breiter, D. (2007). Examining the motivation, perceived performance, and behavioral intentions of convention attendees: Evidence from a regional conference. Tourism Management, 28, 399-408.

65. Simpson, K. (2000). Customer satisfaction and behavioural intentions in a rural community museum environment. Journal of Quality Assurance in Hospitality \& Tourism, 1(3), 1-27.

66. Simpson, P. \& Siguaw, J. (2008). Destination word of mouth: The role of traveler type, residents, and identity salience. Journal of Travel Research, 47(2), 167-182.

67. Sirakaya, E., Petrick, J. \& Choi, H. (2004). The role of mood on tourism product evaluations. Annals of Tourism Research, 31(3), 517-539.

68. Thompson, B. (2000). Ten Commandments of structural equation modeling. In L. Grimm \& P. Yarnold, eds. Reading and understanding more multivariate statistics, 261-283. Washington, DC: American Psychological Association.

69. Um, S., Chon, K. \& Ro, Y. (2006). Antecedents of revisit intention. Annals of Tourism Research, 33(4), 1141-1158.

70. Williams, P. \& Soutar, G. (2009). Value, satisfaction and behavioral intentions in an adventure tourism context. Annals of Tourism Research, 36(3), 413-438.

71. Yoon, Y. \& Uysal, M. (2005). An examination of the effects of motivation and satisfaction on destination loyalty: A structural model. Tourism Management, 26, 45-56.

72. Yuan, J. \& Jang, S. (2008). The effects of quality and satisfaction on awareness and behavioral intentions: Exploring the role of a wine festival. Journal of Travel Research, 46 (February), 279-288.

73. Yucelt, U. (2000). Marketing museums: An empirical investigation among museum visitors. Journal of Nonprofit \& Public Sector Marketing, 8(3), 3-13.

74. Yüksel, A. \& Yüksel, F. (2001). The expectancy-disconfirmation paradigm: A critique. Journal of Hospitality \& Tourism Research, 25(2), 107-131.

75. Yüksel, A. \& Yüksel, F. (2007). Shopping risk perceptions: Effects on tourists' emotions, satisfaction and expressed loyalty intentions. Tourism Management, 28, 703-713.

76. Yüksel, A., Yüksel, F. \& Bilim, Y. (2010). Destination attachment: Effects on customer satisfaction and cognitive, affective and conative Loyalty. Tourism Management, 31, 274-284.

77. Žabkar, V., Brenčič, M. \& Dmitrović, T. (2010). Modelling perceived quality, visitor satisfaction and behavioural intentions at the destination level. Tourism Management, 31, 537-546.

78. Zeithaml, V. (1988). Consumer perceptions of price, quality, and value: A means-end model and synthesis of evidence. Journal of Marketing, 52 (July), 2-22.

79. Zeithaml, V., Berry, L. \& Parasuraman, A. (1996). The behavioral consequences of service quality. Journal of Marketing, 60, 31-46. 


\section{APPENDIX}

The Links between Quality, Satisfaction and Loyalty in the Tourism Literature: A Review

\begin{tabular}{|c|c|c|}
\hline \multicolumn{1}{|c|}{ Link } & Proposed And Confirmed & Proposed But Not Confirmed \\
\hline Quality $\rightarrow$ Satisfaction $(\mathrm{Q} \rightarrow \mathrm{S})$ & $5,13,14,16,23,26,31,32,39,43$ & $15,19,34$ \\
\hline Quality $\rightarrow$ Loyalty $(\mathrm{Q} \rightarrow \mathrm{L})$ & $4,5,11,14,16,19,23,43$ & $13,15,31,32,34,39$ \\
\hline & $1,2,3,5,6,7,8,9,10,11,12,13,14,15$, & 19,24 \\
Satisfaction $\rightarrow$ Loyalty $(\mathrm{S} \rightarrow \mathrm{L})$ & $17,18,20,21,22,23,25,26,27,28,29,30$, & \\
& $31,32,33,34,35,36,37,38,39,40,41,42$, & 43 \\
\hline
\end{tabular}

Studies:

01. Kozak (2001)

02. Petrick, Morais \& Norman (2001)

03. Petrick \& Backman (2002)

04. Petrick (2004a)

05. Petrick (2004b)

06. Sirakaya, Petrick \& Choi (2004)

07. Bigné, Andreu \& Gnoth (2005)

08. Duman \& Mattila (2005)

09. Yoon \& Uysal (2005)

10. Alegre \& Cladera (2006)

11. Gallarza \& Saura (2006)

12. Rodríguez del Bosque, San Martín \& Collado (2006)

13. Um, Chon \& Ro (2006)

14. Castro, Martín Armario \& Martín Ruiz (2007)

15. Chen \& Tsai (2007)

16. Ho \& Lee (2007)

17. Hui, Wan \& Ho (2007)

18. Jang \& Feng (2007)

19. Lee, Petrick \& Crompton (2007)

20. Lee, Yoon \& Lee (2007)

21. Severt, Wang, Chen \& Breiter (2007)

22. Yüksel \& Yüksel (2007)

23. Campo \& Yagüe (2008)

24. Chen \& Tsai (2008)

25. Chi \& Qu (2008)

26. De Rojas \& Camarero (2008)

27. Füller \& Matzler (2008)

28. Li \& Petrick (2008)

29. Rodríguez del Bosque \& San Martín (2008)

30. Simpson \& Siguaw (2008)

31. Yuan \& Jang (2008)

32. He \& Song (2009)

33. Huang \& Hsu (2009)

34. Hutchinson, Lai \& Wang (2009)

35. Kim, Kim \& Kim (2009)

36. Williams \& Soutar (2009)

37. Alegre \& Garau (2010)

38. Campo-Martínez, Garau-Vadell \& Martínez-Ruiz (2010)

39. Chen \& Chen (2010)

40. Hosany \& Gilbert (2010)

41. Hosany \& Witham (2010)

42. Yüksel, Yüksel \& Bilim (2010)

43. Žabkar, Brenčič \& Dmitrović (2010) 